\title{
7. Locating Seven Rivers
}

\author{
Fiona Powell
}

\section{Introduction}

In December 1890, while on patrol down the west coast of northern Cape York Peninsula (NCYP), accompanied by Senior-Constable Conroy and a few native troopers of the Thursday Island Water Police, Sub-Inspector Charles Savage visited 'the Seven Rivers'. ${ }^{1}$ From this place, the party went south to the mouth of the Batavia (now Wenlock) River. There they met the chief or mamoose of the Seven Rivers tribe, ${ }^{2}$ a man identified as Tongambulo (variations Tong-ham-blow, ${ }^{3}$ Tongamblow ${ }^{4}$ and Tong-am-bulo ${ }^{5}$ ) and also known as Charlie in one account. ${ }^{6}$ At the time of this meeting, Sub-Inspector Savage was seeking another candidate for induction into government policies intended 'to civilize the Natives of Cape York Peninsula' ${ }^{7}$ The first NCYP Aboriginal person to have had this experience was Harry, also known as King Yarra-ham-quee, and described as the 'mamoose of the Jardine River'. ${ }^{8}$ This man had been taken to Thursday Island earlier in the year:

where he underwent a course of instruction and when he had sufficiently understood what was required of him was taken back and made king, his subjects and several visitors, Natives of Prince of Wales Island, being present. ${ }^{9}$

\footnotetext{
1 'Conciliating the Natives', Torres Straits Pilot, 6 December 1890, and published in The Queenslander, Saturday 27 December 1890: 1216 [hereafter 'Conciliating the Natives' Torres Straits Pilot].

2 Savage, Charles 1891, Letter to the Honourable John Douglas, Government Resident Thursday Island, dated 11 February 1891, Queensland State Archives, Item D 143032, File - Reserve. Europeans used the term 'mamoose' to distinguish local headmen in Torres Strait island communities. The honorific was then bestowed on mainland local Aboriginal men of importance. It survives today as a surname, spelt variously as Mamoose, Mamus, Mamoos.

3 Douglas, John Government Resident, Thursday Island, Letter to the Honourable The Chief Secretary, 16 February 1891 in Queensland State Archives, Item ID 143032, File - Reserve.

4 Smith, George, 'Cruise of the S.S. "Vigilant" The Blacks of the Gulf Country', The Brisbane Courier, Tuesday 31 March 1891: 3.

5 Report dated 31 July 1891 to the Home Secretary from The Honourable John Douglas, Government Resident, Thursday Island, in Queensland State Archives, Item ID 143032, File - Reserve. It is clear from this report that 'Tang-am-bulo' is Douglas's later rendering of the name of the man referred to in an earlier report as Tong-ham-blow and as the chief of the Seven Rivers tribe.

6 'Conciliating the Natives', Torres Straits Pilot.

7 'Conciliating the Natives', Torres Straits Pilot.

8 'Conciliating the Natives', Torres Straits Pilot.

9 Savage, Charles 1891 Letter to The Honourable John Douglas, Government Resident Thursday Island dated 11 February 1891, in Queensland State Archives, Item ID 143032, File - Reserve.
} 
Tongambulo accompanied Sub-Inspector Savage and his party to Thursday Island. One early account noted that he:

cannot speak a word of English, nor had he been near a white man's abode until brought into our midst. One of his first impressions on rambling around the barracks was conveyed in the question he asked Kio ${ }^{10}$ the interpreter: "Why white man could make the fowls stay about the house, when in his country they all flew away and could not be caught?" Kio explained as best he could to the mamoose that the white man possessed a magical power which was sufficient to tame anything; Charlie will probably realise this after he has spent two weeks here as the host of the Government. The rough edges of his savagery will be toned down a bit. ${ }^{11}$

The Chief of the Seven Rivers was also 'made King in the same manner as the Chief of the Jardine River had been,' ${ }^{12}$ the Hon. John Douglas observing that:

Tong-ham-blow, the chief of the Seven Rivers, is a very noticeable man. He is grey headed and has a most remarkable physiognomy. When he was brought to us here he knew nothing, of course, of the world or its inhabitants beyond the environment of the Seven Rivers, but during the three weeks he remained with us he made good use of his eyes and ears, and the impressions thus conveyed to him will doubtless be of use to us in our future communications with him. ${ }^{13}$

The placename 'Seven Rivers' occurs in the NCYP ethno-historical, linguistic and genealogical records and in both the English and the NCYP Creole toponymic lexicons. However, it has never been officially gazetted despite its continuing importance for those residents of Injinoo (formerly Cowal Creek) ${ }^{14}$ whose ancestors originated from places named 'Seven Rivers', 'Seven River', 'Severn River' and 'Seventh River'. ${ }^{15}$ Although in the records these placenames

10 This man's name is variously represented in the NCYP records as Keyo and Kaio. His role in the exploration and settlement of NCYP is the subject of the author's current research.

11 'Conciliating the Natives', Torres Straits Pilot.

12 'Conciliating the Natives', Torres Straits Pilot.

13 Douglas, John Government Resident, Thursday Island, Letter to the Honourable The Chief Secretary, 16 February 1891. Queensland Department of Lands Reserve File 91-14 Part 1, Mapoon Aboriginal Reserve, Transfer 1726/1, Box 167, Queensland State Archives.

14 The name of the community was changed by Governor in Council from Cowal Creek to Injinoo on 2 September 1989 (Queensland Place Names online search, retrieved http://www.nrm.qld.gov.au/property/ placenames/details.php?id=16700).

15 The author first met Aboriginal people who originated from Seven Rivers in 1970 at Hope Vale, a Lutheran mission settlement north of Cooktown. They told her that as children, they had been removed from NCYP and sent to Cape Bedford mission, north of Cooktown and that during World War II, along with other Cape Bedford residents, they were sent to the Woorabinda Aboriginal Settlement, before resettlement at Hope Vale, which was established after the end of World War II. In 2003, the author met relatives of these people at Injinoo, and this meeting led to this research about NCYP placenames. 
are associated with the coast north of Port Musgrave, there is not a settled view about whether they refer to the same place or to several places. This paper presents the results of my enquiries about this toponym. ${ }^{16}$

NCYP Creole, which is the first language of many Injinoo residents, has particular features that affect the pronunciation and hence the recording and subsequent interpretation of some placenames. For example, in NCYP Creole there is no phonemic/phonetic difference made between names such as 'McDonnell' and 'MacDonald', which are important family names and placenames in NCYP history. Neither does NCYP spoken Creole make a formal or overt marking of the difference in the grammatical category of number in nominals or noun phrases so that names like 'Seven Rivers' and 'Seven River', which are readily distinguished in spoken and written English, are: 'simply [sévanriva] or similar. This has been true from the earliest contact period'. ${ }^{17}$ Because NCYP spoken Creole does not distinguish between names such as 'Seven River' and 'Seven Rivers', one of the first tasks in analysing records about these placenames is to determine if such records refer to the same or to different places. This issue is particularly relevant for researchers who consider the NCYP linguistic, ethnohistorical, genealogical and official records. Many of these records contain information elicited from NCYP Creole speakers. Contextual clues that might assist the interpretation of these records include the identity of the recorder and source, and the time and place when the record was created.

\section{Seven Rivers}

Although 'Seven Rivers' was not gazetted as an official placename, as shown in Maps 1 and 2, nineteenth century and early twentieth century maps of Cape York associate this placename with the coastal area north of Port Musgrave. The several river mouths that are passed when sailing between Thursday Island and Port Musgrave are a feature of this coast and it is likely that the placename 'Seven Rivers' originated during nineteenth century navigational surveys of the NCYP west coast. However, as shown by Maps 1 and 2, the early records differ with respect to location and extent of the area represented as 'Seven Rivers'.

\footnotetext{
16 I am indebted to many people for their valuable and generous assistance during the research and preparation of this article. In particular, I would like to express my thanks to the descendants of ancestral people associated with Seven Rivers, Seven River, Severn River and Seventh River and the MacDonnell telegraph station, to the late Mr Jack Callope, the late Dr Terry Crowley, Helen Harper, Professor Bruce Rigsby, Mr Bill Kitson, and Mr Geoff Wharton for their assistance with source materials; Professor Bruce Rigsby for his advice with respect to NPA Creole placenames; Dr Ben Smith and Dr Nicky Horsfall for their constructive comments on early drafts of this article, Dr Nicky Horsfall for her aerial photograph of the Skardon River, and Dr Luise Hercus for her persistent encouragement and advice with linguistic transcription.

17 Professor Bruce Rigsby, pers. comm. 19 March 2004. I am indebted to Professor Bruce Rigsby for his advice and information about NCYP creole. For further details about this language, see Crowley and Rigsby 1979: 153-208.
} 
The earliest record found that shows this placename's location is a map attached to the 1891 Annual Report of the Government Resident of Thursday Island. ${ }^{18}$ A copy of this map attached to an 1896 letter $^{19}$ from Archibald Meston to the Under Colonial Secretary is represented as Map 1.

The broken lines on this map mark several rivers that flow into the Gulf of Carpentaria and suggest the possibility that their representation is tentative. This map was made before the north-west coast and inland areas of the NCYP mainland had been comprehensively surveyed. It differs from contemporary maps, such as that represented below as Map 3, with respect to the location of some of the west coast rivers and the McDonnell telegraph station. This telegraph station was one of several transmitter stations that were constructed during 1886-1887 for the overland telegraph line which followed the route of the 1883 Bradford expedition and which linked Thursday Island with the mainland (Bradford 1962). The telegraph line opened on 25 August 1887 with transmitter stations positioned about 100-120 km apart at Musgrave, Coen, Mein, Moreton, McDonnell and Patterson. From Patterson a line was laid on the seabed to connect with Thursday Island. Later, the Patterson station was moved to Peak Point and renamed Cape York telegraph station. The McDonnell telegraph station began operating in 1887 and closed in 1929. The station comprised a substantial building with a large produce garden. Early NCYP maps, like those represented as Maps 1 and 2, locate the McDonnell telegraph station on the 'Skardon' headwaters. Map 1 represents this watercourse as the most southern of the rivers in the 'Seven Rivers' area. Map 1 also suggests that a watercourse (not named) that debouches into the sea just south of Crab Island might be the most northern of the rivers in the area asociated with the placename 'Seven Rivers'.

18 Attached to his annual report for 1891 is a map of northern Cape York Peninsula, which shows the placename 'Seven Rivers' along the west coast of the Peninsula. It also shows the McDonnell telegraph station on the headwaters of the 'Skardon' River (Douglas, John, 'Annual report of the Government Resident at Thursday Island', Queensland Votes and Proceedings of the Legislative Assembly, Volume 2, 1892: 1029-1035). I am indebted to Geoffrey Wharton for drawing my attention to this map and to Dr Nicky Horsfall for providing me with a copy. This same map is also contained in Appendix XXVI of the Minutes of Evidence taken before the 1908 Pearl-Shell and Beche-de-Mer Royal Commission (Queensland Parliamentary Papers, vol. 2, 1908, pp. 691-695).

19 Letter with map attached from A. Meston to the Under Colonel Secretary dated 14 March 1896, Queensland State Archives Item ID 847539 Series No 5253 Item Top Numbered 11535. 


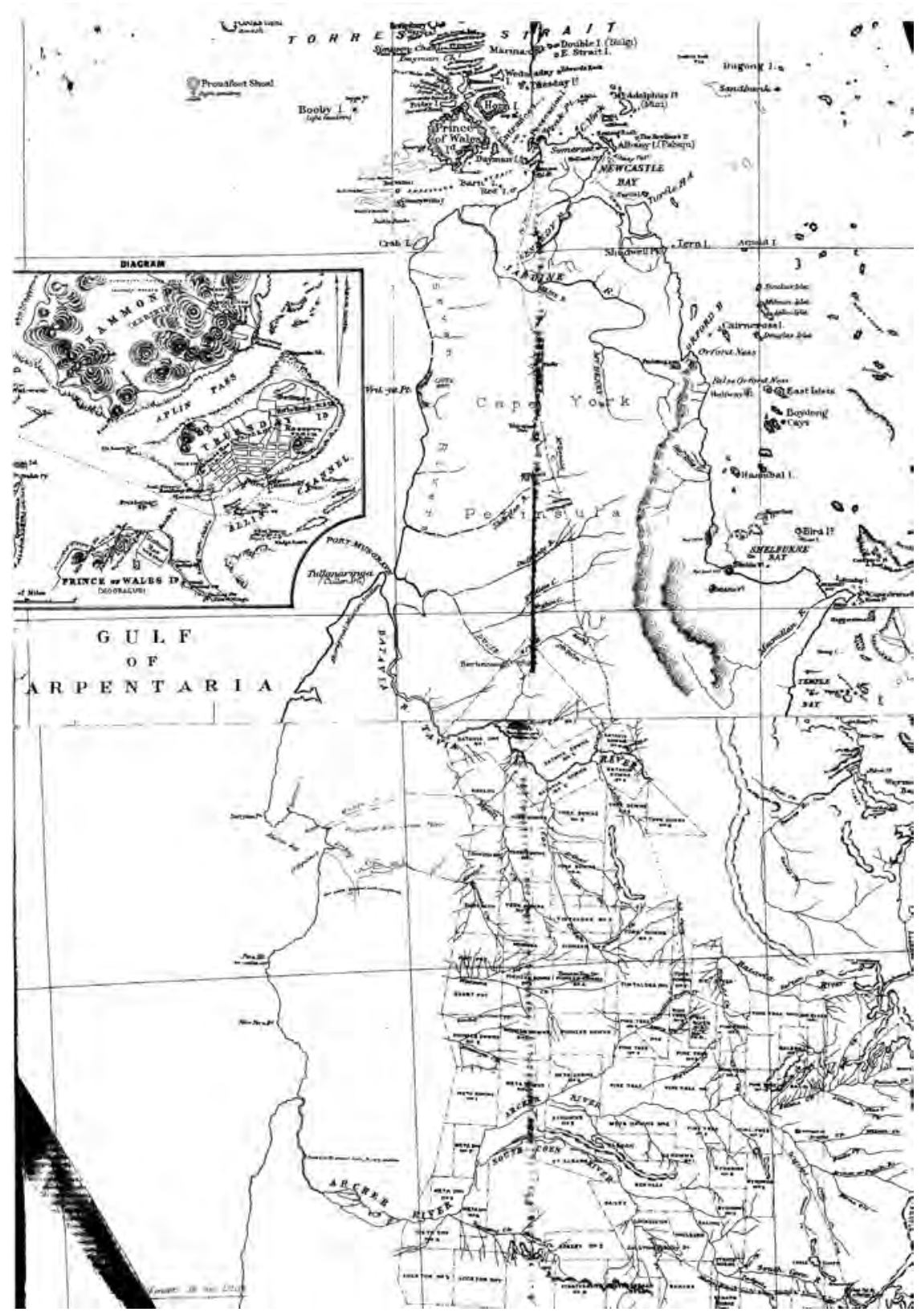

Map 1: An early map of Cape York. ${ }^{20}$

20 Map attached to Queensland State Archives Item ID 847539 Series No 5253 Item Top Numbered 11535. 
The representation of 'Seven Rivers' in Map 1 corresponds approximately with the earliest written description found of the 'Seven Rivers' area as: 'that tract of country known as the 'Seven Rivers' - i.e., the coast district between the Jardine River and the Batavia' (Queensland Police Commissioner, W.E. ParryOkeden 1898: 4). An account by Parry-Okeden's contemporary, the Aboriginal Protector Dr Walter Roth, provides a slightly different view. When describing the location of the 'Gamiti', one of several Aboriginal groups associated with the Port Musgrave region, Roth placed this group: 'on the north shore of Port Musgrave, i.e. between the Ducie R.[iver] ${ }^{21}$ and the Seven Rivers country' (Roth: 1900: 2; 1910: 96). ${ }^{22}$ The assistant government geologist Clements F.V. Jackson who accompanied Roth on a 1902 visit to Mapoon, associated the placename 'Seven Rivers' with the coastal area on the northern side of Port Musgrave, noting that:

The portion of the coast north of the Batavia River for about 60 miles [c.96.5 km] is known as the "Seven Rivers" district, and with the exception of Vrilya Point, which is the only prominent feature between Port Musgrave and the north-west corner of the peninsula, the whole of the land surface along the coast is characteristically low-lying and sandy (Jackson 1902: 7).

Other records clearly associate the river known today as the 'Skardon' with the placename 'Seven Rivers'. One early record mentions the 'Scarsden (or 7 Rivers) district' (Hardie and Robinson 1891) 23 $^{3}$ and descriptions by others (Savage 1891; Douglas 1891) about the 'Seven Rivers' camp, establish its location near the coast and just south of the Skardon River.

My research found that the placename 'Seven Rivers' appeared in official records, at least until $1923,{ }^{24}$ although, as shown by Maps 1 and 2, its location varied.

Although Maps 1 and 2 represent a section of the west coast of NCYP as 'Seven Rivers', they differ with respect to the location and extent of this area. Map 1 represents the coastal region between Crab Island and the 'Skardon River'

21 The Government surveyor and geologist, R. Logan Jack considers that this river was first named 'Palm Creek' and then re-named the 'Ducie' by Frank Jardine during the construction of the Telegraph Line, in 1887 (Jack 1921: 319).

22 There is nothing in Roth's report to indicate that the term 'country' in this quotation is a reference to the notion of 'country' as this term is used today to signify Aboriginal traditional homelands or territory.

23 The Reverends Andrew Hardie and Samuel Robinson wrote to The Hon. The Premier of Queensland on 10 August 1891 that 'It has been accordingly decided that this district with Cullen Point as headquarters and a suitable reserve southward along the coast \& eastward up the Batavia would be a suitable location for the Federal Assembly's Mission to the aborigines. From Cullen Point we can influence the Blacks of the Scarsden (or 7 Rivers) district (Queensland State Archives, Item ID 143032, File - Reserve, letter dated 10 August 1891). The contemporary spelling of this watercourse is 'Skardon'.

24 I am indebted to Mr Bill Kitson, formerly the Curator - Museum and Lands \& Surveying, Department of Natural Resources, Queensland for this information. Mr Kitson kindly checked through the archival holding available to him and could not find the placename 'Seven Rivers' on maps printed after 1925. 
as 'Seven Rivers', while the later Map 2 associates this placename with a less extensive coastal area between just south of Vrilya Point northwards to a place opposite Crab Island. Both maps depict the McDonnell telegraph station in the headwaters of the 'Skardon', a location which is inconsistent with more recent maps such as represented in Map 3. A comparison of the early and contemporary maps of the west coast of NCYP show further changes in the representation of places named 'Seven Rivers, 'Skardon River' and the 'McDonnell telegraph station'.

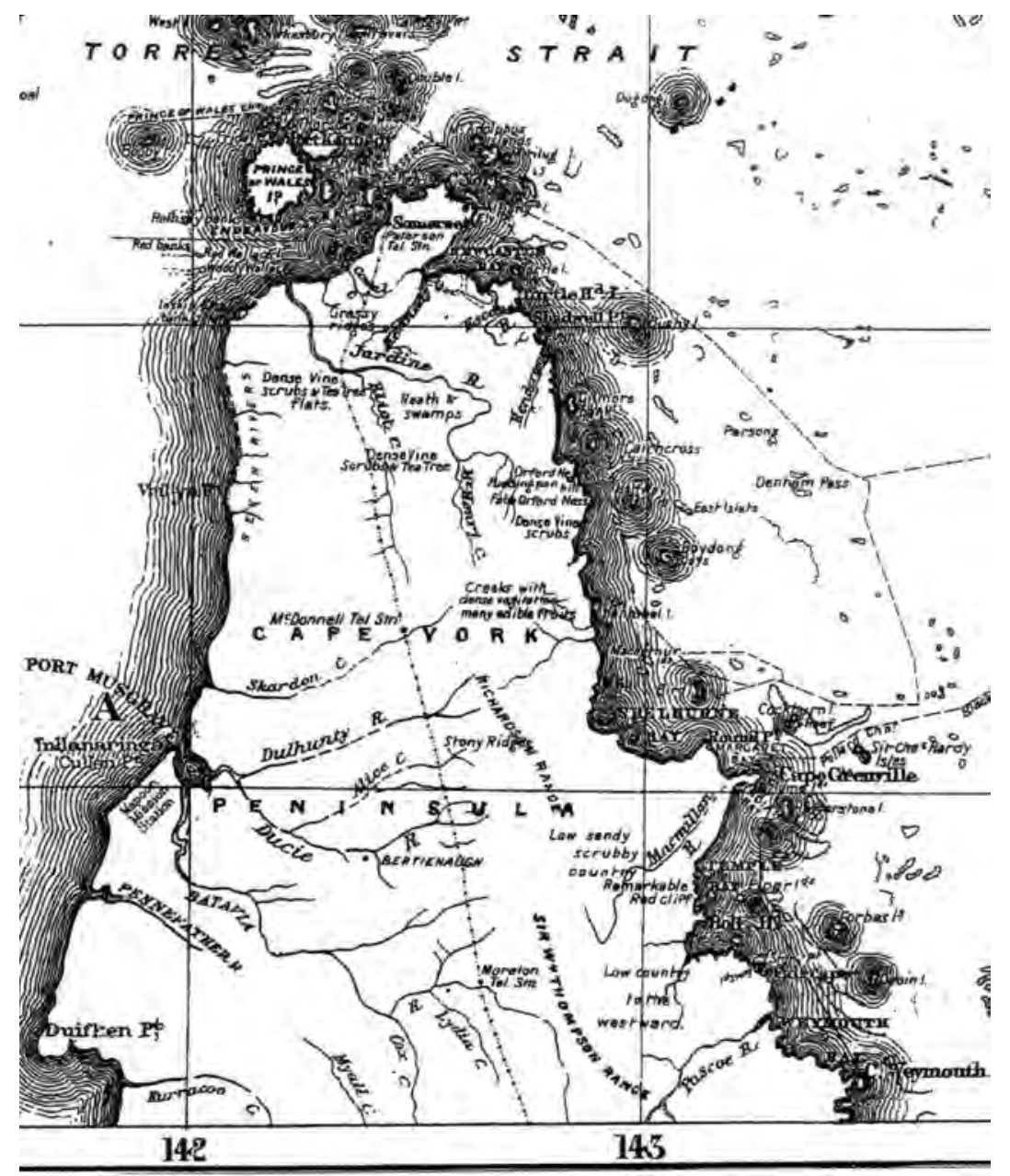

Map 2: Representation of a portion of a map of Cape York Peninsula, printed in $1924 .^{25}$

25 Map 2 shows a portion of Sheet 6 of the 16 M Series 1 map sheets, printed in 1924 and based on the most recent surveys and information procurable constructed at the Surveyor General's Office, Brisbane, with additions and corrections to 1897, and used with the permission of the Department of Natural Resources and Mines, Queensland. 


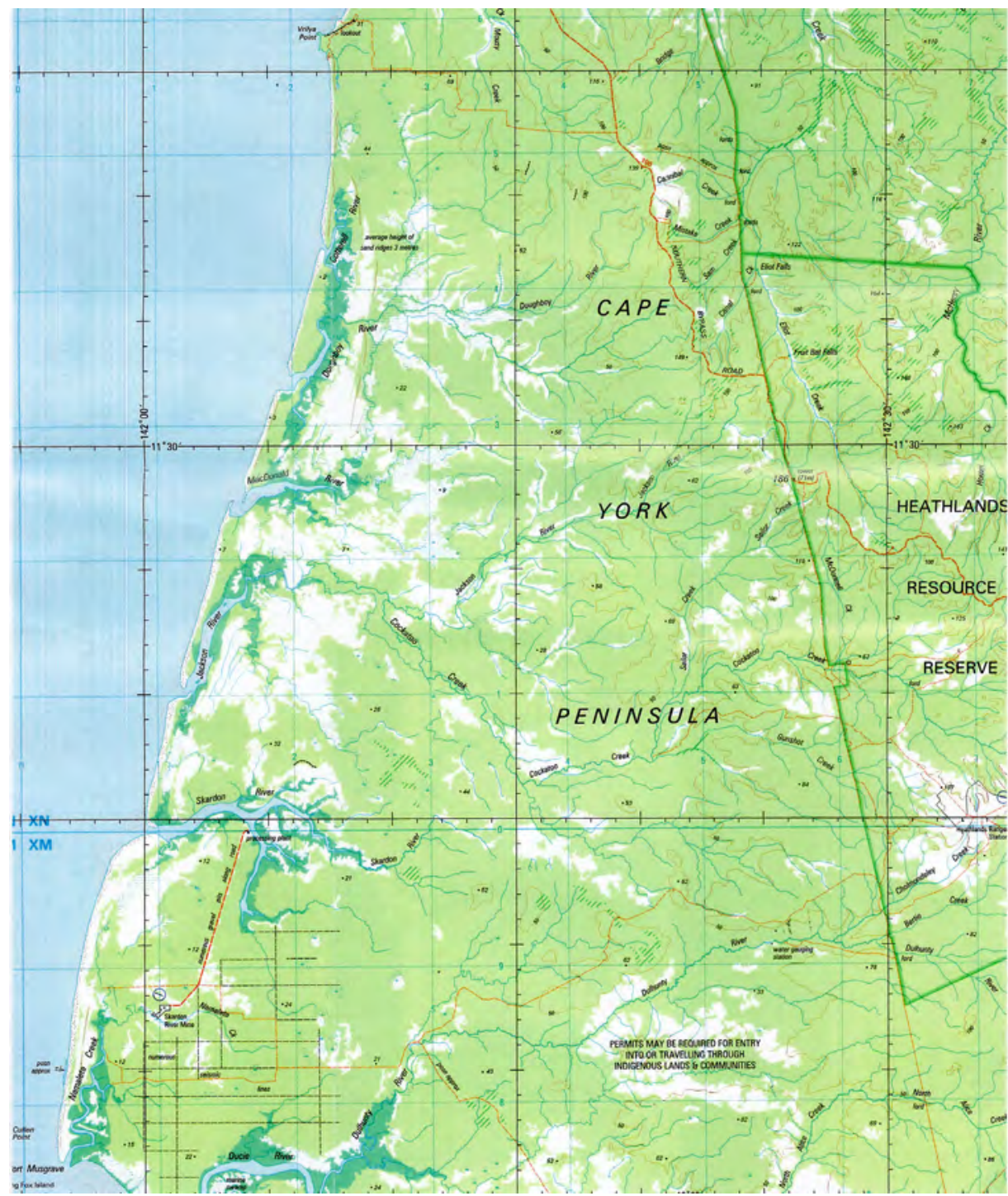

\section{Map 3: Representation of a portion of a 2004 map of the west coast of NCYP. ${ }^{26}$}

An inspection of Maps 1, 2 and 3 shows that the placename 'Seven Rivers' has disappeared from the more recent cartographical records, and that there are differences between the early and more recent maps in the location of places identified as the 'Skardon River' and the 'McDonnell telegraph station'. On contemporary maps such as the one shown as Map 3, the McDonnell telegraph

26 Map 3 represents a portion of the Jardine River Queensland NATMAP Sheet 1:250 000 scale prepared in 2004 by Geoscience Australia. 
station is located near the confluence of McDonnell (formerly 'MacDonald ${ }^{27}$ ) and Cockatoo creeks. The latter watercourse is a tributary of the 'Jackson River', which does not appear on the early maps.

\section{1 'Seven Rivers' in NCYP linguistic and ethno- historical records}

Notwithstanding its omission from contemporary maps of Cape York Peninsula, in the region's ethno-historical and linguistic records, 'Seven Rivers' is used to distinguish a portion of the coast north of Port Musgrave and Aboriginal people associated with this area. The linguist Terry Crowley, who conducted field research at Bamaga during 1975-76, described the Seven Rivers area as: 'the very narrow coastal stretch from the northern side of Port Musgrave as far as the Doughboy River and also the inland area of Crystal Creek and the middle Jardine River' and identified the seven watercourses associated with this area as the Jardine, Macdonald ${ }^{28}$ Skardon, Doughboy, Ducie, Jackson and Crystal (Crowley 1983: 310). However, Maureen Fuary and Shelley Greer (1993: 11) reported that the first river of the 'Seven Rivers' area is a small watercourse just south of the Jardine River that is known locally as 'No. 1 River'. Crowley associated the 'Seven Rivers' area with Uradhi ${ }^{29}$ (Ankgamuthi) speakers and his 1983 map represents this region as extending from the northern shore of Port Musgrave to just north of the Jardine River (Crowley 1983: 306). The representation by Greer and Fuary (2008: 4, Map 1) of the area associated with the '7 Rivers People' shows a similar north-south extent. They describe the area associated with the '7 Rivers People' as:

... the land on the west coast of the Peninsula from the Dulhunty River north to somewhere between the Jardine River and the location of the present settlement [Injinoo] (Greer and Fuary 2008: 6).

\footnotetext{
27 The map of the Hann Shire 1912-1919 names the creek near the site of the McDonnell telegraph station as 'Macdonald'. More recent maps name this creek 'McDonnell'.

28 This watercourse is not the same as the one named McDonnell (formerly Macdonald) Creek, which is near the site of the now defunct MacDonnell telegraph station.

29 Following Hale (1976), Crowley (1983) adopted the name Uradhi as a generic name for the several lingusitic varieties associated with the NCYP region. Hale (1964: 252) noted one speaker used the term 'Uradhi' (meaning 'having ura' for 'this') as the name for his language, which was Hale considered was one "of several dialects of a single language spoken from the tip of Cape York Peninsula south to the Dalhunty [sic] R. on the west and Cape Grenville on the east."
} 


\subsection{Changes associated with the placename 'Skardon'}

In NCYP records, 'Seven Rivers' (or one of its variants) is associated with a watercourse named the 'Skardon', a name that is also represented variously in the written records as Schardon, ${ }^{30}$ Scardon, ${ }^{31}$ and Scarsden ${ }^{32}$ and in NCYP Creole sometimes as 'Scott'. According to R. Logan Jack (1921: 318) ${ }^{33}$ the river now named the 'Dulhunty' 34 that joins the Ducie River, which debouches into Port Musgrave, was first named the 'Skardon' by the Jardine brothers Frank and Alexander during their 1865 overland trek from Carpentaria Downs to Somerset. ${ }^{35}$ Later, they renamed this watercourse the 'Dulhunty'.$^{36}$ On early maps, such as those represented as Map 1 and Map 2, the 'Dulhunty' is clearly distinguished from the 'Skardon', which is shown to enter into the sea north of Port Musgrave. Maps 1 and 2 represent the McDonnell telegraph station in the Skardon headwaters. However, on contemporary maps, the site of the former McDonnell telegraph station is located in the headwaters of the 'Jackson River' which flows into the sea north of the watercourse now known as the 'Skardon'. Nowadays, this latter watercourse is sometimes referred to as the 'Last River' by Mapoon Mission residents because it is regarded as the last of the seven rivers passed by boats travelling from Thursday Island before they arrive at Mapoon. ${ }^{37}$

As Maps 1 and 2 show, the Jackson River is not represented in the early maps of the west coast of NCYP, which suggests that this part of the NCYP west coast was incompletely and/or incorrectly mapped, with the consequence that on these early maps 'Skardon' (or one of its variants) seems to have been used to refer to two quite separate watercourses. This conflation of the Skardon and

30 Douglas 1891 in Queensland State Archives, Item ID 143032, File - Reserve, letter dated 10 August 1891.

31 Woods 1891.

32 Spelling used in the letter by the Rev. Hardie to the Hon. Premier of Queensland dated 10 August 1891, about a visit to the Batavia River region. Queensland Department of Lands Reserve File 91-14 Part 1, Mapoon Aboriginal Reserve, Transfer 1726/1, Box 167, Queensland State Archives.

33 Robert Logan Jack was appointed Government Geologist for North Queensland in 1877 and for all of Queensland in 1879. During 1879-1880, he led a geological expedition that explored the eastern side of Cape York Peninsula from Cooktown to Somerset. His account of this trip and the explorations of others in Cape York Peninsula were published later in his Northmost Australia (Anon. 1922 Obituary: Robert Logan Jack). 34 Information from the Queensland Placenames On-line Data base. The database refers to 2 sources - The Queenslander, 10 February 1900, pp. 266-267; and F.J. Byerley, Narrative of the overland expedition of the Messrs. Jardine from Rockhampton to Cape York, Brisbane, 1867, p. 49.

35 The droving party left Carpentaria Downs in October 1864 and reached Somerset in early March, 1865. The route taken traversed the headwaters of some of the rivers flowing into Port Musgrave, including the Dulhunty River. The party had several violent encounters with Aboriginal groups along the way, the last being just north of the Batavia River (now named the Wenlock), and this was 'the last occasion on which the party was molested, their sable adversaries having, probably, at length learned that "they were worth better alone," and never again shewing themselves' (Byerley 1867: 48).

36 The river was renamed after Robert Dulhunty, a NSW pastoralist, whose sons were friends of the Jardine brothers. Information from the Queensland Placenames On-line Data base, which refers to The Queenslander, 10 February 1900: 266-267.

37 Geoffrey Wharton, pers. comm. 10 July 2003. 
Jackson rivers and location of the McDonnell telegraph station on the Skardon River seems to have continued until at least 1940, as can be seen on maps made by Ursula McConnel (1939) and Norman Tindale (1940) of the territorial associations of various groups (termed 'tribes') in the Cape York region. This conflation should be taken into account when considering records based on information recorded from elderly NCYP Aboriginal people which sometimes associate 'McDonnell' or 'MacDonald' with the 'Skardon' and which refer to early placename locations that are no longer current.

\subsection{Locations of places named 'Seven Rivers'}

The earliest record found that provides details about the location of a specific place named 'Seven Rivers' is an 1885 report by Constable Percy Phillpotts of the Thursday Island Water Police. While on route from Thursday Island to the mouth of the Batavia (now Wenlock) River to return some Aboriginal men and boys rescued from bêche-de-mer recruiters, Phillpotts reported that he:

dropped anchor at $8 \mathrm{pm}$, about a mile and half, off the entrance to a place known as the Seven Rivers, and distant about twenty-eight miles from the Batavia River. ${ }^{38}$

This distance - 28 miles - converts into either $45 \mathrm{~km}$ (when miles are read as land miles) or $51.8 \mathrm{~km}$ (when miles are read as nautical miles). ${ }^{39}$ These calculations locate Phillpotts' 'Seven Rivers' near the mouth of the 'Jackson River' ${ }^{\prime 0}$ of contemporary maps.

The next record found that mentions a specific place named 'Seven Rivers' is an 1891 report by Sub-Inspector Charles Savage which details his patrol down the Peninsula west coast to check on the welfare of the Jardine and Seven Rivers people, following the appointment by the Thursday Island government officials of their respective 'kings' or 'mamooses'. Charles Savage reported that:

Permanent camps have been established at the Jardine River and Seven Rivers and large "Gunyas" have been built. Coco-nuts, sweet potatoes, pumpkin and watermelons have been planted and are growing well at the Jardine River. The matter now stands thus. The Natives at the Jardine and the Seven Rivers are aware that the Government takes an

\footnotetext{
38 Phillpotts, Percy 1885 Report for the Government Resident, Thursday Island, QSA COL/A444.

39 I have used these conversions, provided courtesy of the Department of Defence, Canberra: 1 nautical mile $=1.15625$ miles; 1 nautical mile $=1.85$ kilometres and 1 mile $=1.609$ kilometres. I am indebted to Officers from Australian Surveying and Land Information Group [AUSLIG] associated with Geoscience Australia who provided advice about the distance in nautical and land miles and kilometres between the mouth of the Skardon and the northern shore of Port Musgrave, using contemporary maps.

40 According to R. Logan Jack, the Jackson River might be the Carpentier of the 1606 Dutch maps (Jack 1921: 318).
} 
interest in them, is prepared to protect them when necessary from injustice and expects their assistance in punishing crimes committed by their tribes. They have been shown how to make houses of the bark and told that it is better for them to live in houses than to roam aimlessly about. They understand this completely but whether they will continue as well as they are going on now remains to be seen. I believe with constant supervision they will. ${ }^{41}$

Some months after submitting the above report, Sub-Inspector Savage accompanied an official party, which included the Thursday Island Resident, The Honourable John Douglas and two clergymen, to Port Musgrave to assess its suitability as a site for a mission for Aboriginal people. While on route, the party:

anchored that night off the Schardon River, which falls into the sea about twelve miles north of Port Musgrave and about ninety miles from Port Kennedy which we had left in the morning. ${ }^{42}$

As described in John Douglas' report, this watercourse is approximately 19.3$22.2 \mathrm{~km}$ from the northern point of the mouth of Port Musgrave. ${ }^{43}$ This location, approximately 12 nautical miles north of Cullen Point (at the south head of Point Musgrave) establishes that the 'Schardon River' is the 'Skardon River' of contemporary maps. It is also clear that John Douglas' 1891 surveying party did not anchor near Phillpotts' 'Seven Rivers' (i.e. they did not anchor at the mouth of the river now known as the Jackson, which is approximately $36 \mathrm{~km}$ (c.22 miles) north of Port Musgrave). The official party visited: 'a native camp about two miles south of the Schardon, where we found about fifty natives of Tang-am-bulo's tribe'. ${ }^{44}$ This description places the native camp about three kilometres south of the mouth of this river, posibly near a place identified by McKeown (1993) as 'Footprint Swamp' 45 near the headwaters of Namaleta Creek (once known locally as 'Mouth River'46), which flows into Port Musgrave. Another record (Smith 1891) mentions a native camp associated with 'Mamoose

41 Report from Sub-Inspector Charles Savage to the Hon. John Douglas, Government Resident, Thursday Island dated 11 February 1891.

42 Douglas, John, Report to The Honourable the Chief Secretary Re a visit to Batavia River with the Revd. A. Hardie \& Revd. S. Robinson, dated 31 July 1891, Queensland State Archives, Item ID 143032, File - Reserve.

43 His 12 miles can be estimated as either $19.3 \mathrm{~km}$ or $22.2 \mathrm{~km}$ (depending on whether 12 miles is read as 12 land or nautical miles).

44 Douglas, John, Report to The Honourable the Chief Secretary Re a visit to Batavia River with the Revd A. Hardie \& Revd S. Robinson, dated 31 July 1891, Queensland State Archives, Item ID 143032, File - Reserve. It is clear from this report that 'Tang-am-bulo' is Douglas's rendering of the name of the man referred to in an earlier report as Tong-ham-blow and as the chief of the Seven Rivers tribe.

45 This site was mapped by Dr Frank McKeown in 1993 (pers. comm. 10 January 2013 from Dr Nicky Horsfall who also has conducted research in this region).

46 The late Mr Jack Callope, who grew up at Mapoon Mission told me that in early mission times this was the name used for the watercourse that is now known as Namaleta Creek. Mr Callope referred to the people who lived in that area as the 'Seven River tribe' (notes made during an interview with Mr Jack Callope, 8 November 2004). 
Tongamblow' and locates this place 'off one of the Seven Rivers' and 42 miles (c.67.6-77.8 km) south of Crab Island. From these two descriptions, it is clear that the Savage and Smith records refer to the same camp.

\subsection{Alternative placenames: Seven River, Severn River and Seventh River}

The NCYP records also mention the placenames 'Seven River' (Hey 1899; ${ }^{47}$ Crowley 1975; Rigsby 1972), 'Severn River' (Shanahan 1897) and 'Seventh River' ${ }^{48}$ A 1908 record refers to a place identified as 'Seven River Lagoon' ${ }^{49}$ but does not include enough information to determine its location.

The earliest mention of the placename 'Seven River' was found in a letter dated 4 August 1899 from the Reverend Nicolas Hey (missionary at Mapoon from 1891 to 1926) to R.H. Mathews, in which the Revd Hey notes that:

The name of the tribe north of Batavia River between Seven River and towards MacDonald Telegraph Station is Gâmete (Hey 1899).

There is not sufficient information in this letter to determine either the location of Hey's 'Seven River' or whether this placename refers to a particular watercourse or to a camp known as 'Seven River'. A more recent record made in 1972 by Professor Bruce Rigsby clearly connects 'Seven River' with the 'Skardon River'. Rigsby (1972) recorded from a NCYP man named Larry MacDonald, ${ }^{50}$ who was bilingual in the Uradhi (Atambaya) and NCYP Creole languages, the term Eerrunyu for the 'seven [th?] river' and that:

Well they call that Seven River Langgus name Eerrunyu - you come this way between Seven River and Mapoon - well Whiteman he call Skardon - that river blo McDonnell, McDonnell River junction Ithinmanyu, call im Ithinmanyu - Langgus name - go up Inbinh - Langgus name Inbinh. ${ }^{51}$

It seems from this account that the Uradhi placenames Ithinmanyu and Inbinh could refer to places associated with the headwaters of the Jackson River, in the vicinity of the former McDonnell telegraph station. A transcription of a wordlist compiled by Terry Crowley (1975) from the same informant contains

\footnotetext{
47 Hey, Rev. Nicolas Letter to R.H. Mathews, dated 4 August 1899.

48 This placename occurs in records pertaining to an Aboriginal woman named Kitty.

49 This is recorded in the 1908 report by Constable Whelan.

50 Larry MacDonald was born about 1900 at 'MacDonnell', which may be a reference to the former MacDonnell telegraph station and/or the area where it was located. He died at Bamaga in 1981.

51 Transcription by Dr Helen Harper of an excerpt of side 2 of Field Tape number 72/30, recorded by Professor Bruce Rigsby. Helen Harper also made the following free standard English translation of this excerpt: 'Well the Language name for the seven[th?] river is Eerrunyu. If you come up this way between Seven River and Mapoon, white people call it Skardon River - the river from the McDonnell River junction. Its Language name is Ithinmanyu. Go up further, the Language name is Inbinh' (Harper 2003).
} 
the terms Ilunyung? and Atowiyangung ${ }^{52}$ for 'Seven River' and Skardon River respectively. ${ }^{53}$ The ? suggests some doubt about the term Ilunyung, but there is no further information available which explains this uncertainty. Crowley's recording of different Uradhi (Atampaya) names for 'Seven River' and 'Skardon River' suggests the possibility that the placenames elicited from Larry MacDonald may refer to different portions of watercourses distinguished by these names and/or to places associated with these watercourses.

\subsection{Severn River}

M.W. Shanahan's account of an 1896 expedition by a prospecting party that he led mentions the 'Severn River'. This expedition traversed the country from Patterson (the first site of the most northern of the Cape York telegraph stations) towards the Richardson Range. ${ }^{54}$ Their guide and informant for the many Aboriginal placenames noted in Shanahan's account of the expedition was an Aboriginal man named Kio, ${ }^{55}$ whose descendants now live at Injinoo. Kio was also a guide and interpreter for Sub-Inspector Savage and others during their exploratory forays along the NCYP west coast. ${ }^{56}$ In the upper Ducie River area, Shanahan noted:

... great local excitement owing to the Severn River natives (who inhabit the western coast north of the mouth of the Batavia) having sent the Ducie boys a challenge to fight. The cause of the quarrel was an old one lying in abeyance since Charley, a brother of the Ducie mamoose, captured a Severn River gin. ${ }^{57}$

The 'Batavia' mentioned by Shanahan is a reference to the watercourse known today as the Wenlock River. Shanahan's association of the 'Severn River natives' with the west coast north of the mouth of the Batavia is clearly a reference to the area that records made a few years earlier associated with the 'Seven Rivers' tribe, and his 'Severn River' is most probably a variant representation of the placename 'Seven Rivers' and/or 'Seven River'. The variant form 'Severn River' occurs in some later records. For example, an 1937 record mentions the

\footnotetext{
52 Another possible transcription of this term is Atomyangung.

53 Names reported in the transcript of Tape 14, A4137a and listed in the Atampaya (Uradhi) elicitation materials, Crowley Collection MS 1002, AIATSIS, Canberra. I am indebted to Dr Luise Hercus for advice about the transcription of these two words.

54 This account was published in serial form in The Queenslander. There is also a manuscript version, the original held at the John Oxley library.

55 Shanahan MS 1897: 19. Shanahan described him as a 'Red Island native [and] one of the mainland native police ... [and] one of the best trackers in the far North' (Shanahan MS 1897: 14-15).

56 In later records, Kio's name is represented as 'Kaio'. Kio assisted Sub-Inspector Savage in his west coast patrols and also helped the founding Mapoon missionaries during their first weeks at Port Musgrave.

57 Shanahan MS 1897: 39.
} 
'McDonnell tribe' and the 'Severn and Jardine River men' at Cowal Creek ${ }^{58}$ while an account of the settlement of Cape York Aboriginal people at Cowal Creek (now named Injinoo), states that:

Twenty-five years ago, the remains of three powerful Cape York tribes - the Red Island, Severn River, and Cape York tribes - which had for generations been in an almost constant state of warfare, and had also been a menace to white settlers and travellers, decided to bury the hatchet. ${ }^{59}$

Mentions of the 'Severn River natives who inhabit the western coast north of the mouth of the Batavia' by Shanahan (1897: 39) and of the 'Severn River tribe' in the 1939 account are clearly references to the 'Seven Rivers' people, some of whom were encountered in 1891 by the Thursday Island Government Resident John Douglas and his party, at their camp just south of the present day Skardon River. During 2003-2010, I compiled additional information about these people from their descendants and the NCYP ethno-historical, linguistic and genealogical records that were available to me for my consideration.

\subsection{Ethnonyms associated with the NCYP west coast}

In the published records, the coastal area north from Port Musgrave to the Jardine River is associated not only with the Seven Rivers (var. Seven / Severn River) tribe or natives but also with the following ethnonyms: ${ }^{60}$

Ungpaygen,Ungcumtae and Oyn-Ohyunce (Savage 1892)

Umbaijan, ${ }^{61}$ Yandaigan $^{62}$ (Meston n.d.); Yandigan (q), west of Cootung to Jardine River and Dolumthurra (w) 'Seven Rivers' (Meston 1896: 14)

Yadigan $^{63}$ (Shanahan 1897: 44)

Am-Komti, Ya-ra-kim (Parry-Okeden 1897: Appendix G)

Gâmete $^{64}$ (Hey 1899)

\footnotetext{
58 'Blacks Show Civic Spirit', The Sydney Morning Herald, Saturday 26 June 1937: 23.

59 Walkabout, 1 December 1939: 47. The author is not named but may be one of the anthropologists who conducted research at Cowal Creek and elsewhere in Cape York Peninsula in the 1930s (e.g. Ursula McConnel or R. Lauriston Sharp).

60 This list should be regarded as a list in progress, and as complete as known to me, at the time of writing. 61 Recorded on an unpublished sketch map, (Meston's Book of Pasted Notes: 77, OM64-17, John Oxley Library) and not included in Meston's 1896 list of Tribes Interviewed (see Meston 1896: 14).

62 According to Meston, the name derives from Yanta 'cave' and daigan 'inhabitant' (Map \& Notes on Tribes of Cape York, Book of Pasted Notes: 77, Meston Collection, OM64-17 JOL).

63 This name used by Shanahan (1897: 44) for a "Cape York tribe" that "occupied the coast south of the Small River to south of the Jardine River, Vrilya Point."

64 Represented as Gametty by Matthews 1900:131.
} 
Indigenous and Minority Placenames

Gamiti (Roth 1900)

Ngathokadi and Nggamadi (Lauriston Sharp 1939: 257; and Ngathokadi (Lauriston Sharp 1939: 265) ${ }^{65}$ and An' Gamoti (Seven Rivers) / Nggamadi /Anggamudi (Lauriston Sharp 1933-34) ${ }^{66}$

Nggammatti (Thomson 1934: 219) ${ }^{67}$

Ngkamadyi / Nggamadi (McConnel 1939: 54, 60) ${ }^{68}$

Nggamadi (Tindale 1940 map; ${ }^{69}$ 1974: 183)

Ankamuti (Tindale 1940: 154; 1974: 164)

Gamati (Rigsby 1972)

Gamuthi (Crowley 1981: 146)

Angkamuthi and Uradhi (Crowley 1983: 306, 310)

Uradi, Angkamuti (Nonie Sharp 1992: Map 2: 12)

Barranggu, Nggamati, Ankamuti (Davis 1993) and

Anggamudi (Horton 1994 Vol. 2: 50).

Crowley (1983: 310) has established that some of these names are variant representations of the name of a language distinguished as either Nggammadi (var. Gamati, Gâmete, Gametty, Ngkamadyi, Nggamadi, Ngammatti), which is a form used by the initial CV-dropping speakers south of Port Musgrave or as Angkamuthi (var. Ankamati / Angkamuthi / Angkamuti / Anggamudi / An'Gamoti). Other names in this list refer to entities that might not be equivalent. For example, depending on the context, Uradhi (var. Uradi) and Angkamuthi (var. Angkamuti, Anggamudi) are terms that may distinguish either a language or dialect or language-named group or language group. ${ }^{70}$ Some of the names, such as Savage's Oyn-Ohyunce, Meston's 'Dolumthurra' and Davis' 'Barranggu', ${ }^{71}$

65 Sharp (1939: 265: note 14) states that his Ngathokadi are called Athokurra by Thomson (1934). McConnel (1939: 60) recorded Sharp's Ngathokadi as (Ng)uthukuti.

66 These names occur in Lauriston Sharp's unpublished field notes and genealogies that are held in the Lauriston Sharp Papers, \#14-25-2618, Division of Rare and Manuscript Collections, Cornell University Library. 67 Thomson (1934: 219) describes the Nggammatti as "a tribe occupying a very large tract of country, extending from Port Musgrave to a little north of Vrilya Point."

68 According to McConnel (1939: 80): “The Ngkamadyi, Roth's Gamiti (Sharp: Nggamadi), occupied the coastland north of the Ducie River and south of the Yumakundyi of the Jardine River".

69 Tindale (1974: 183) states: "In the text of 1940 the heading Ngerikudi was in error associated with data for this tribe instead of Nggamadi. The map however, was correctly marked."

70 See for example, Sharp (1992: $12 \mathrm{ff})$; Crowley (1983: $308 \mathrm{ff})$.

71 This name appears on the 1993 Davis map of Australia's Extant and Imputed Traditional Aboriginal Territories. It might be a local name but unfortunately there is no further information about this name in the associated publication by Stephen Davis and J.R.V. Prescott's Aboriginal Frontiers and Boundaries in Australia. 
have been recorded only once and are completely dissimilar to the other names reported for this region. The suffix 'thurra' in Meston's Dolumthurra - 'Seven Rivers' suggests that this might be the name of a local clan group ${ }^{72}$ and his use of quotation marks for Seven Rivers suggests an acknowledgement that this is a local or unofficial placename.

Omitted from this list but of interest because of the time of its recording and its similarity to Hey's 'Gâmete' and Roth's 'Gamiti' is Meston's 'Gammatee', which he located 'east of Bertie Haugh'73 (Meston 1896: 14), which is inland from the west coast. It is probable, however, that Meston's 'Gammatee' is a reference to the group represented as 'Gâmete' and 'Gamiti' by Hey and Roth respectively. The inconsistency between Hey and Roth on the one hand and Meston on the other in relation to the location of Gâmete (variation Gamiti, Gammatee) suggests that either their or Meston's placement of this group might be an error or that one of these observers may have recorded an outlier of this group or that the area inhabited by members of this group was more extensive than the narrow strip of the coast north of Port Musgrave that the early maps associate with the placename 'Seven Rivers'. The brief descriptions mentioned above suggest the probability of this last possibility, for they associate this group with an area that extends from the coast into the hinterland to include the Ducie River region and an area described as 'towards the McDonnell telegraph station'.

\subsection{Seven Rivers in the genealogical records}

The NCYP genealogical records include the names of persons reported born at 'Seven Rivers', 'Seven River' and 'Seventh River'. The records of one person report a birthplace by all these placenames, which clearly shows that, in this case, 'Seven Rivers' = 'Seven River' = 'Seventh River' ${ }^{74}$ The NCYP genealogical records mention persons with the surnames 'Seven Rivers', 'Seven River', 'Severin', 'River' and '7 River/s'. The use of placenames for surnames is common in Cape York Peninsula genealogies and signifies a close connection between bearer and place. However, my research found that these particular placenames as surnames have not survived because early NCYP naming practices precluded their bestowal on the children of parents so surnamed. Typically, in the early days, children took their father's (or, more rarely, their mother's) first name as their last name and spouses used their partners' first name as a surname.

Terry Crowley considers that 'some of the names in Davis's map are a bit linguistically incorrect. ....and my maps also have names attributed to areas that do not appear on Davis's map, and some of his names I do not recognise. I would not want to comment on the signficance of these discrepancies' (Crowley 1995: 136).

72 Shanahan (1897: 45) notes that in Cape York languages, 'the termination "urra" - "durra", "murra," "gurra," - is the general verbal indication of present action'.

73 This was the name of Jardine's cattle property, the homestead of which was situated on the Ducie River.

74 These placenames occur in the records of one NCYP family. I am indebted to a member of this NCYP family for providing copies of these records and for permission to use this information for this article. 
Thus, for example, the children of Peter Seven River (who is estimated born about 1860 or before) had the surname 'Peter' and the An' Gamoti (Seven Rivers) couple interviewed by the anthropologist, R. Lauriston Sharp in 1933, appear in his records as 'Jack Emley' and 'Emily Jack'. After the Second World War, mainstream Australian naming practices became widely adopted by NCYP people. However, by this time, there were no children born at Injinoo (then Cowal Creek) to persons having the surname 'Seven Rivers' (or one of its variations) so that Seven Rivers as a surname was discontinued and is found only in the historical records.

\subsection{Lauriston Sharp's Seven Rivers people}

R. Lauriston Sharp's research, undertaken at Cowal Creek during 1933-1934, directly associates the placenames 'Seven Rivers' and 'Seven River' with several of the ethnonyms listed above. Among Sharp's unpublished Cowal Creek genealogies are those for three persons named Frank Doyle, Jack Emley/Jack Sergeant and his wife, Emily Jack, all of whom are identified as An'Gamoti (Seven/7 Rivers). ${ }^{75}$ Sharp (1939: 257) also used the form 'Nggamadi' as an alternative spelling for 'An'Gamoti'. Jack Emley died at Cowal Creek in 1942. ${ }^{76}$ His death certificate reports that he was born at 'Seven River' around 1893 and was the son of Peter Seven River and Otemba/Wootinba Seven River. His wife, Emily Jack is reported born at 'Seven River' around 1891 and the daughter of Lily and Jimmy Woosup/Robson. Frank Doyle's records report that he was born around 1886 at McDonnell ${ }^{77}$ and was the son of Jack Snake and his wife Mary. Descendants of Sharp's An'Gamoti (Seven Rivers) people reside at Injinoo (formerly known as Cowal Creek) and describe themselves as members of the Seven Rivers Angkamuthi people.

\subsection{The Seven Rivers Skardon camp and the Seven Rivers People today}

There has been no systematic search for traces of the former Seven Rivers camp that was located south of the Skardon River, where The Hon. John Douglas and his party landed in 1891 during their journey to Port Musgrave to select a site suitable for a mission to Aborigines. An archaeological survey conducted in 1993 noted scatters on the Skardon River bank. ${ }^{78}$ A kaolin mine is now located

75 These are the Lauriston Sharp Cowal Creek genealogies numbered 5 (for Frank Doyle), 6 (for Jack Emley) and 7 (for Emily Jack) that are in the Lauriston Sharp Papers, \#14-25-2618, Division of Rare and Manuscript Collections, Cornell University Library.

76 Information recorded on his death certificate. The informant for this certificate was his wife Emily.

77 This is a reference to the McDonnell telegraph station.

78 These were noted as lying on the southern shoreline of the Skardon River in 1993 during an archaeological survey for the Kaolin Mining and Processing Project. (See Yates and Quartermaine 1993: 19). 
in the area south of the Skardon River. Aboriginal mining of kaolin (local name ruah) occured both prior to and after the establishment of the Mapoon Mission in 1891 and kaolin was used by Aboriginal people for body decoration, bush medicine for stomach and bowel complaints, and, in during the time of the Mapoon Mission (1891-1963), was mixed with water to make whitewash to whiten the internal walls of the mission's houses. ${ }^{79}$

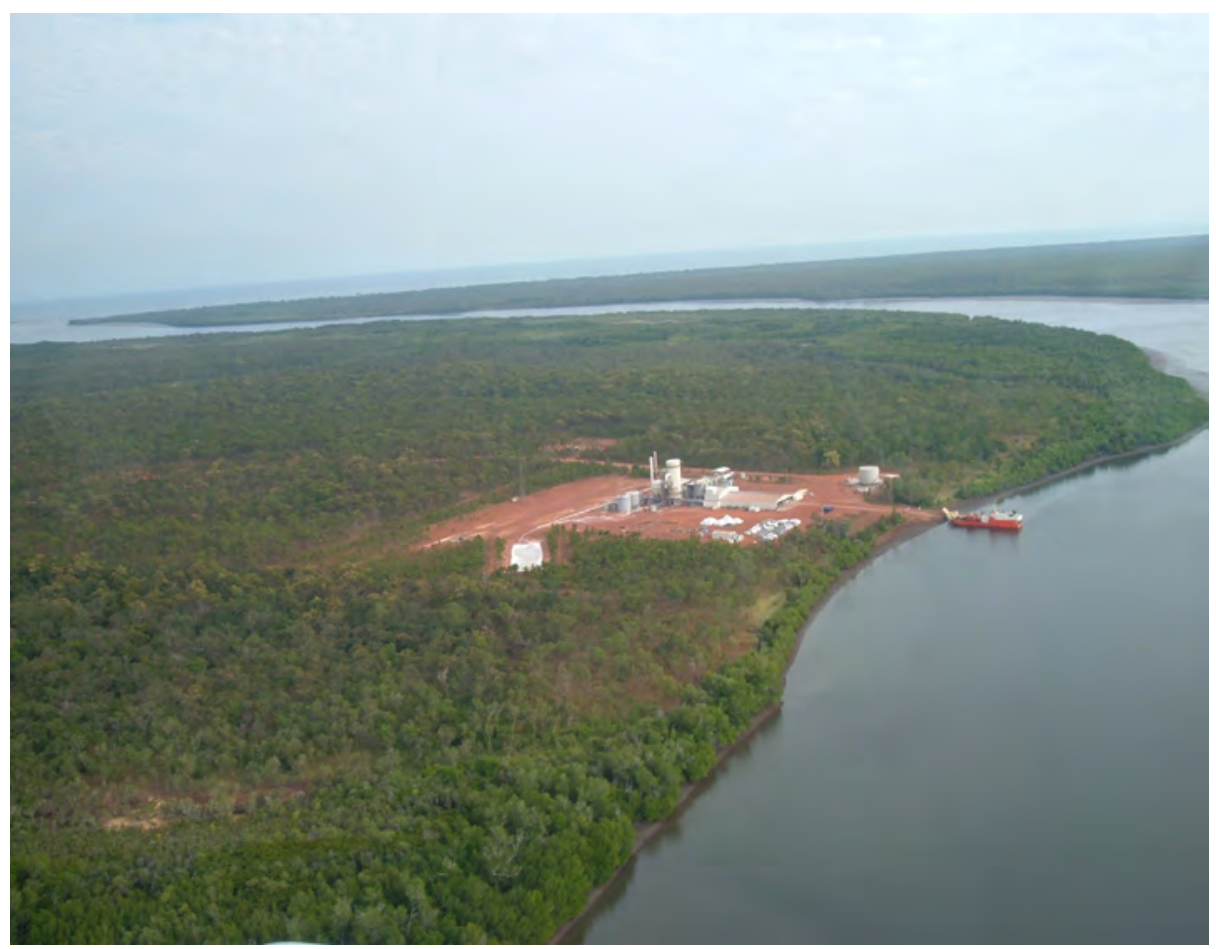

\section{Image 1: Aerial photograph of the Skardon River, showing its mouth and the kaolin mine barge landing.}

In Seven Rivers Angkamuthi oral histories, their ancestors are described as 'walkabout people' whose movements over a large tract of NCYP were determined by seasonal changes, religious responsibilities, political issues and employment opportunities. These ancestors travelled between coastal camps to the Moreton and McDonnell telegraph stations and also regularly visited Mapoon Mission in its early years, where some attended school. However, with the exception of a few who were either removed by government authorities to Mapoon or who went there voluntarily, none became permanent residents of this Presbyterian mission. Instead, on the advice of an east coast man named Alick Whitesand, ${ }^{80}$

79 Dr Nicky Horsfall, pers. comm. 10 January 2013.

80 Alick Whitesand is recorded in the Register of Baptisms for St Michael and All Angels (the Anglican Church at Injinoo) as also named Alick Taitaia Onarwatanu and born about 1868 at Whitesand, a place on 
they trekked north to settle at the place now known as Injinoo (previously named 'Cowal Creek' and once called 'Small River'). Whether several small family groups undertook this journey over a period of time or there was a mass relocation of all the Seven Rivers people is not recalled, although the available records suggest the latter possibility. ${ }^{81}$ Nor do the Seven River Angkamuthi people at Injinoo recall the precise date when this relocation occurred. However, the genealogical records ${ }^{82}$ and the 1939 Walkabout account suggest that it most probably happened during the period 1913-1914.

\section{Conclusion}

My inquiries have established that 'Seven Rivers' is a bilingual placename that is represented in the NCYP records also as 'Seven River' and 'Severn River'. In these records, this placename has several distinct but associated meanings, and has been and continues to be used by the Indigenous people of Cape York to distinguish:

- a substantial portion of the west coast of NCYP;

- specific places on the west coast of NCYP;

- a place of birth and/or origin of particular ancestors; and

- a contemporary Aboriginal group, whose members are descended from forebears associated with 'Seven Rivers'.

My research found that the placename 'Seven Rivers' probably originated during the early navigational surveys of NCYP and entered the lexicon of NCYP Aboriginal Creole speakers who do not make the singular v. plural distinction of native English speakers. Although the placename 'Seven Rivers' appears on early NCYP maps, it has not survived developments in the mapping of this region. These include the identification of the Jackson River, the re-mapping of the Skardon River, and the re-positioning of the former MacDonnell telegraph station from the Skardon River of the early maps to the headwaters of the Jackson River of the contemporary maps. Researchers investigating the signficance of place associations reported in NCYP genealogical, linguistic and ethno-historical records will need to take these cartographic changes into account as well as giving consideration to not only the time when records were created, but also to the role of NCYP Creole speakers in their creation.

the east coast of NCYP. He was the husband of a Seven Rivers Angkamuthi woman named Kitty. 'Whitesand' is most probably the place that the linguist, Terry Crowley (1983: 310) noted as 'the area known locally as "White Sands" (i.e. Double Point and nearby areas of Shelbourne Bay)'.

81 See the account recorded by Nonie Sharp from Snowy Woosup in Sharp 1992: 99-102.

82 An inspection of the available records found no records of births at 'Seven Rivers' after 1913-1914. 
Many people who are descended from ancestors regarded as originating from 'Seven Rivers' are known today by themselves and others as the Seven Rivers Angkamuthi. Although this placename no longer appears on contemporary maps, it is part of NCYP Aboriginal oral tradition and the above account of its location in the region's ethno-historical records may contribute to its restoration in NCYP's written history.

\section{References}

Anonymous 1912-1919, Map of Hann Shire 1912-1919, Queensland State Archives Item ID 629670, map 16M/SH5.N.D./C.

— 'Blacks Show Civic Spirit', The Sydney Morning Herald, Saturday 26 June 1937: 23

- 1922, 'Obituary: Robert Logan Jack, L.L.D., F.G.S., M.I.M.M.', The Geographical Journal 59(4): 318-319.

— 1937, Walkabout, 1 December 1939: 47.

Bradford, J. R. 1962, 'The Cape York Expedition of 1883', Journal of the Royal Historical Society of Queensland 6(4): 1014-1028.

Byerley, F.J. 1867, Narrative of the overland expedition of the Messrs. Jardine from Rockhampton to Cape York, Brisbane.

Crowley, T. 1975, Atampaya (Uradhi) elicitation, narratives and song words: transcription of tapes LA4137a-9a, LA4140a-b, 1. 48-131, MS 1002, Australian Institute of Aboriginal and Torres Strait Islander Studies, Canberra.

- 1981, 'The Mpakwithi dialect of Auguthimri', in Handbook of Australian Languages, R.M.W. Dixon and Barry J. Blake (eds), The Australian National University Press, Canberra, Volume 2: 146-194.

- 1983, 'Uradhi', in Handbook of Australian Languages, R.M.W. Dixon and Barry J. Blake (eds), The Australian National University Press, Canberra, volume 3: 306-428.

Crowley, T. and B. Rigsby 1979, 'Cape York Creole', in Languages and their Status, Timothy Shopen (ed.), Winthrop Publishers, Cambridge: 153-208.

Davis, S. 1993, Australia's Extant and Imputed Traditional Aboriginal Territories [map], Distributed by Melbourne University Press, Melbourne. 
Indigenous and Minority Placenames

Davis, S. and J.R.V. Prescott 1992, Aboriginal Frontiers and Boundariesin Australia, Melbourne University Press, Melbourne.

Douglas, J. 1891, Report to The Honourable the Chief Secretary Re a visit to Batavia River with the Revd. A. Hardie \& Revd. S. Robinson, 31 July 1891, Queensland State Archives, Item ID 143032, File - Reserve.

Douglas, J. 1892, 'Annual report of the Government Resident at Thursday Island', Queensland Votes and Proceedings of the Legislative Assembly, Volume 2: 1029-1035.

Fuary, M. and S. Greer, 1993, Preliminary Report on Families and People's Connections to Country for the Community of Injinoo, Cape York Peninsula. Prepared for the Injinoo Land Trust.

Greer, S. and M. Fuary 2008, 'Comunity consultation and collaborative research in Northern Cape York Peninsula - a retrospective', Archaeological Heritage 1(1): 5-15.

Hale, K. L. 1964, 'Classification of Northern Paman languages, Cape York Peninsula, Australia: a research report', Oceanic Linguistics 3(2): 248-265.

- 1976, 'Phonological developments in a Northern Paman language: Uradhi', in Languages of Cape York, Peter Sutton (ed.), Australian Institute of Aboriginal Studies, Canberra: 41-49.

Hardie, Revd. A. and the Revd. S. Robinson 1891, Letter to The Hon. the Premier of Queensland, dated 10 Aug 1891, Queensland State Archives, Item ID 143032, File - Reserve.

Harper, H. 2003, Transcription of Professor Rigsby's Field tapes numbers 72/14 and $72 / 20$.

Hey, Reverend N. 1899, Letter to R.H. Mathews dated 4 August 1899 in the R.H. Mathews Papers, MS8006/1/2/5, National Library of Australia, Canberra.

Horton, D. (ed.) 1994, The Encyclopaedia of Aboriginal Australia, Australian Institute of Aboriginal and Torres Strait Islander Studies Press, Canberra.

Jack, R. L. 1921, Northmost Australia, 2 volumes, Simpkin, Marshall, Hamilton, Kerd \& Co. Ltd, London.

Jackson, C.F.V. 1902, Report on a Visit to the West Coast of the Cape York Peninsula and some Islands of the Gulf of Carpentaria, Department of Mines, Brisbane.

Mathews, R.H. 1900, 'Marriage and descent among the Australian Aborigines. Appendix. Some tribes of Cape York Peninsula', Journal and Proceedings of the Royal Society of New South Wales 34: 131-135. 
McConnel, U. 1939, 'Social organization of the tribes of Cape York Peninsula, North Queensland', Oceania 10(1): 54-72.

Meston, A. n.d., Map \& Notes on Tribes of Cape York, Book of Pasted Notes, Meston Collection, OM64-17, John Oxley Library, Brisbane.

- 1896, Report on the Aboriginals of Queensland, Government Printer, Brisbane.

Parry-Okeden, W.E. 1897, Report on the North Queensland Aborigines and the Native Police, with Appendices, plus map. Government Printer, Brisbane.

- 1898, Condition of the Aborigines. Report of the Commissioner of Police on the Working of "The Aboriginals Protection and Restriction of the Sale of Opium Act, 1897". Report to the Under Secretary, Home Secretary's Department. Presented to both Houses of Parliament.

Phillpotts, Constable P. 1885, Report to the Government Resident, Thursday Island, dated 26 October 1885, Queensland State Archives, Item ID 847175 85/8632.

Rigsby, B. 1972, Aboriginal language: field books 1-8. Field book number 7. MS755, Australian Institute of Aboriginal and Torrest Strait Islander Studies, Canberra.

Roth, W.E. 1900, A report to the Under-Secretary, Home Dept. on the Aboriginals of the Pennefather (Coen) River district and other coastal tribes occupying the country between the Batavia \& Embley Rivers. [visited by the Minister during his last trip] Cooktown 8 January 1900, MS346, Australian Institute of Aboriginal and Torrest Strait Islander Studies, Canberra.

- 1910, Social and Individual Nomenclature. North Queensland Ethnography Bulletin No 18, Records of the Australian Museum, 8 (1): 79 -106.

Savage, C. 1891, Letter dated 11th February 1891 to The Honourable John Douglas, Government Resident Thursday Island, Queensland State Archives, Item ID 143032, File - Reserve.

- 1892, Report to the Commissioner of Police dated 21st May 1892, Queensland State Archives, Item D 847435.

Shanahan, M.W. 1897, 'With the Cape York Prospecting Party: being an account of a trip from Cape York to the Carron Range, with various Peninsular sidelights', MS 1142, Australian Institute of Aboriginal and Torres Strait Islander Studies, Canberra.

Sharp, N. 1992, Footprints Along the Cape York Sandbeaches, Aboriginal Studies Press, Canberra. 
Sharp, R. L., 1933-34 Cowal Creek genealogies numbers 2, 5, and 6 Kaurareg genealogies numbers 9 and 10, and document 43-B (Notes made during interview with Tommy Dodd at Cowal Creek, 16/11/1934) Lauriston Sharp Papers, \#14-25-2618, Division of Rare and Manuscript Collections, Cornell University Library.

— 1939, 'Tribes and totemism in northeast Australia', Oceania 9(3): 254-275.

Smith, G. 1891, 'Cruise of the S.S.Vigilant. The Blacks of the Gulf Country', The Brisbane Courier, Tuesday 31 March 1891: 3.

Sutton, P. (ed.) 1995, Country: Aboriginal Boundaries and Land Ownership in Australia, Aboriginal History Inc., Canberra.

Thomson, D. F. 1934, 'Notes on a Hero Cult from the Gulf of Carpentaria, North Queensland', Journal of the Royal Anthropological Institute 64: 217-235.

Tindale, N. B. 1940, 'Results of the Harvard-Adelaide Universities Anthropological Expedition, 1938-1939, Distribution of Australian Aboriginal Tribes: A Field Survey', with one map Transactions of the Royal Society of South Australia, 64 (1): 140-231.

- 1974, Aboriginal Tribes of Australia: Their Terrain, Environmental Controls, Distribution, Limits and Proper Names, plus map, University of California Press, Berkeley, Los Angeles and London.

Whelan, D. 1908, Report of Acting Sergeant D. Whelan re lepers in Cape York Peninsula, Queensland State Archives, Item ID 847690, Correspondence, letter $09 / 81$.

Woods, W. M. (Reverend) 1891, 'Cape York Peninsula Natives. A Cruise in the Albatross', The Brisbane Courier, Wednesday 10 June 1891: 7.

Yates, A. and G. Quartermaine 1993, 'A Report on an Archaeological Site Survey of the Skardon Kaolin Project, Cape York Peninsula, Queensland', Unpublished report prepared for Venture Exploration NL by Yates Heritage Consultants and Quartermaine Consultants. 
This text taken from Indigenous and Minority Placenames: Australian and International Perspectives, Edited by Ian D. Clark, Luise Hercus and Laura Kostanski, published 2014 by ANU Press, The Australian National University, Canberra, Australia. 